\title{
JEDNOPRZESTRZENNE KOŚCIOŁY ROMAŃSKIE $Z$ TERENU WIELKOPOLSKI
}

\author{
SINGLE-NAVE ROMANESQUE CHURCHES FROM \\ THE WIELKOPOLSKA REGION (GREATER POLAND)
}

\author{
(autoreferat wygłoszony $\mathrm{w}$ trakcie obrony pracy doktorskiej \\ w dniu 20 grudnia 2007 r.)
}

\begin{abstract}
„Wiejskie” ecclesiae laicorum pozostają po dziś dzień niemymi świadkami naszych dziejów; opuszczone, zapomniane i niejednokrotnie popadające w ruinę. Jednoprzestrzenne kościoły romańskie z ziem polskich nie cieszyły się dotąd wśród badaczy większym zainteresowaniem. Wielkopolskie zabytki architektury sakralnej, w przeciwieństwie do analogicznych budowli z Pomorza Zachodniego, Śląska, czy też Nowej Marchii, nie doczekały się dotychczas pełnej monografii. Jedyną, niekompletną, i w dużej mierze już dzisiaj nieaktualną pracą na ten temat jest publikacja Granitowe kościoly wiejskie XII wieku w Wielkopolsce, autorstwa Stanisława Wilińskiego oraz przyczynkarski artykuł pióra Alicji Karłowskiej-Kamzowej dotyczący kwestii ich fundacji.

Głównym celem mojej dysertacji jest prezentacja zbadanych archeologicznie pozagrodowych jednoprzestrzennych kościołów z terenu Wielkopolski, które zostały wzniesione w okresie od 2. poł. XI w. do końca 1. poł. XIII w., w ich kontekście historycznym i osadniczym. O podjęciu badań nad obiektem i włączeniu go do niniejszych rozważań decydowały więc dwa czynniki: po pierwsze - przeprowadzenie badań archeologicznych w jego obrębie, a po drugie - rola kościoła jako podstawowego ośrodka chrystianizacji tzw. terenów wiejskich. Warunki te spełnia sześć kościołów romańskich znajdujących się na terenie historycznej Wielkopolski. W kolejności chronologicznej są to następujące obiekty: kościół p.w. Wniebowstąpienia Najświętszej Marii Panny w Gieczu, kościół p.w. św. Andrzeja w Kościelcu Kolskim, kościół p.w. św. Idziego w Krobi, kościół p.w. św. Marcina w Kazimierzu Biskupim, kościół p.w. św. Leonarda w Lubiniu oraz kościół p.w. św. Piotra w Starym Mieście koło Konina.

W przypadku każdego kościoła uwzględniałem następujące kwestie:

- analizę architektoniczną budowli,

- analizę źródeł pisanych dotyczących kościoła,

- badania archeologiczne oraz kontekst osadniczy,

- oraz patrocinium kościoła.
\end{abstract}


W dotychczasowych studiach nad architekturą romańską wszystkie te problemy traktowane były odrębnie lub w ogóle nie rozpatrywane.

Moje studia nad świątyniami z terenu historycznej Wielkopolski są więc pierwszą od przeszło półwiecza próbą szerszego spojrzenia na omawiane obiekty. Przystępując do badań nad jednonawowymi kościołami romańskimi z terenu Wielkopolski, wielokrotnie spotykałem się z opinią, że temat ten został już wyczerpująco opracowany. Jak się jednak okazało, opinie te nie są zgodne ze stanem faktycznym, a w przypadku niektórych kwestii związanych z tematyką pracy powtórzyć można za Elżbietą Kowalczyk, że ,im bardziej zagłębiam się w źródła i opracowania, tym bardziej zdawał[em] sobie sprawę z faktu, jak wiele, oczywistych zdawałoby się ustaleń [...] wisi w próżni”. Efektem moich studiów nad wymienionymi kościołami są nowe, bardzo interesujące ustalenia odnośnie do tych obiektów. Z powodu obszerności tematu pominę w tym miejscu prezentacje poszczególnych budowli, szczegółowe analizy architektoniczne czy osadnicze, które przedstawiłem w pracy, a skoncentruję się na szczególnie interesujących ustaleniach, które zdołałem poczynić.

Jedną z najważniejszych kwestii, którymi zająłem się w mojej dysertacji, jest problematyka wezwania kościoła usytuowanego na osadzie gieckiej, co przyczyniło się do podjęcia szerszych rozważań nad patrocinium św. Mikołaja. Obserwacja Haliny Manikowskiej, iż „,badania nad kultem świętych wymagają [...] przede wszystkim nowej interpretacji, porzucającej powszechnie przyjęte stereotypy" legła w pewnym sensie u podstaw zajęcia się ponownie kultem św. Mikołaja na ziemiach polskich. Dość powszechne przypisywanie kultowi św. Mikołaja związku ze szlakami komunikacyjnymi można w polskiej literaturze przedmiotu zaobserwować już od ponad półwiecza. Jak się powszechnie sądzi, obserwacja kościołów o tym wezwaniu wskazuje, że najczęściej znajdują się one przy szlakach handlowych. Zjawisko to powszechne jest i w Polsce, co pozwala niekiedy na rekonstrukcje przebiegu dróg handlowych, niepoświadczonych źródłowo. Takie podejście sprawiło, że w literaturze przedmiotu pojawiła się niezliczona ilość targów wczesnośredniowiecznych sytuowanych w miejscowościach, w których znajdowała się świątynia pod wezwaniem św. Mikołaja. Jedną z nich stała się dzisiejsza wieś Giecz założona na terenie wcześniejszej osady przygrodowej. Romański kościół w Gieczu do 1952 r. nosił konsekwentnie, jak starałem się udowodnić, pierwotne wezwanie Najświętszej Marii Panny, w późniejszym okresie uzupełnione o tajemnicę Wniebowzięcia. Od 1952 r. w publikacjach naukowych kościół zaczął funkcjonować pod patrocinium św. Mikołaja, co praktykowane jest do dziś. Uważam, iż zabieg ten miał na celu uprawomocnienie istnienia wczesnośredniowiecznego targu przy grodzie gieckim, którego istnienia nie potwierdza jednak żadne z zachowanych źródeł pisanych. Wynikało to z chęci udowodnienia hipotezy o istnieniu w Gieczu miasta przedlokacyjnego, którego targ był ważną częścią składową. Efekty tej zręcznej manipulacji zagościły w naszej historycznej świadomości na stałe, któż bowiem z tu obecnych nie słyszał o kościele św. Mikołaja na tzw. osadzie targowej w Gieczu. 
Moje studia nad kościołem św. Andrzeja w Kościelcu pod Kołem również przyniosły zaskakujące i nad wyraz ciekawe odkrycia. Obiekt ten był przedmiotem badań archeologicznych w 2003 r., kiedy to rozkopano południową stronę wnętrza świątyni, osiągając niemalże oś podłużną budowli. Niestety, pomimo zniszczenia bez mała połowy pierwotnego układu jej wnętrza efekty tych badań są znikome. Już wstępne rozpoznanie przeze mnie rzutu świątyni wykazało rażącą niezgodność ze stanem faktycznym. Zamieszczany w literaturze rzut kościoła przedstawia świątynię mającą wszystkie ściany tej samej grubości, tymczasem ściana północna w połowie swojej długości jest szersza od reszty o ponad $60 \mathrm{~cm}$, i to właśnie owe $60 \mathrm{~cm}$ kryło w sobie największą niespodziankę. Najprawdopodobniej, co udało mi się odkryć w wyniku przeprowadzonych badań w kościele, poszerzenie ściany służyło jako bieg schodowy w komunikacji partii przyziemia z emporą kościoła aż do około 1600 r., kiedy w wyniku rozbiórki zachodniej ściany kościoła utracił swą funkcję. Wówczas został do połowy swej wysokości zasypany gruzem, a wejście do niego zamurowano. Z obiektem tym wiąże się jednak jeszcze jedna kwestia, której dotąd nie udało się rozwiązać. Asymetryczne położenie biegu schodowego wskazuje, że wejście do niego znajdowało się w jakimś pomieszczeniu zlokalizowanym przy północnej ścianie kościoła, w miejscu, w którym dziś wznosi się gotycka zakrystia.

Równie ciekawe wnioski płyną z badań nad kościołem św. Idziego w Krobi. Obiekt ten w wyniku nowożytnych przebudów stracił nieco na swym średniowiecznym wyglądzie. Pozostało jednak wezwanie, które zaważyło na dotychczasowym postrzeganiu tego obiektu przez uczonych zajmujących się problemami architektury romańskiej. W związku z tym, bez jakiegokolwiek rozpoznania, chronologia tego kościoła została ustalona na schyłek XI w. Jak jednak ujawniły niewielkie sondaże architektoniczne, świątynia ta miała w swej pierwotnej formie przęsło prezbiterialne, co w konsekwencji, dla terenu Wielkopolski, nakazuje daleko idącą powściągliwość odnośnie do tak wczesnego datowania tego obiektu. Równie zagadkowy jest pierwotny wygląd północnej ściany kościoła. Wykonana w 1929 r. jego konserwacja zatarła ślady obecności otworów drzwiowych czy okiennych. Dopiero dziś, po niemalże osiemdziesięciu latach, pojawiają się pęknięcia w miejscach, gdzie winny znajdować się otwory okienne, jak również rysuje się miejsce, w którym prawdopodobnie znajdowało się symetryczne wejście w północnej ścianie kościoła. Rozwiązaniem wszelkich wątpliwości byłoby z pewnością skucie tynków wewnątrz kościoła, niestety tego zabiegu nie udało się dotychczas wykonać.

Jak już wspomniałem, podjąłem również studia nad kościołem św. Marcina w Kazimierzu Biskupim oraz kościołem św. Leonarda w Lubiniu. Wstępne wyniki eksploracji archeologicznych w tych obiektach zostały opublikowane, a autorzy badań przedstawili zarazem najistotniejsze informacje dotyczące owych obiektów. W przypadku Kazimierza Biskupiego można się tylko zastanawiać, dlaczego nie kontynuowano wykopów w celu zbadania zachodniej partii obiektu. I chociaż odkryty tam fragment poprzecznego fundamentu przewiązanego ze ścianą zachodnią nasuwa możliwość istnienia w tym miejscu wieży zachodniej, to jednak jednoznacznie nie zostało to stwierdzone. 
Kościół św. Piotra w Starym Mieście pod Koninem to ostatni z analizowanych przeze mnie obiektów architektury. Pomimo że zbadano większość wewnętrznej powierzchni kościoła, a od zakończenia badań mija właśnie 20 lat, to nie ukazało się, poza lakoniczną notką w „Informatorze Archeologicznym”, opracowanie badań. Nie znalazła wyjaśnienia kwestia obecności empory zachodniej w kościele, choć są ku jej istnieniu dość solidne przesłanki. $Z$ dość dużym, jak sądzę, prawdopodobieństwem fundację tej świątyni należy łączyć z Władysławem Odonicem, który po śmierci Władysława Laskonogiego w 1231 r. silnie związał się z Kościołem, nadając m.in. w 1232 r. przywileje mennicze i łowieckie biskupowi poznańskiemu. Odonic dokonywał również nowych nadań majątkowych na rzecz instytucji kościelnych, z których najważniejsze były przywileje immunitetowe dla arcybiskupstwa gnieźnieńskiego w (1234) oraz dla biskupstwa poznańskiego (1237). Czy jednym ze wspomnianych nadań i fundacji był kościół staromiejski w archidiecezji gnieźnieńskiej, nie sposób stwierdzić. Jednakże wszystkie pośrednie przesłanki nakazywałyby łączyć fundację kościoła św. Piotra z tym władcą.

Odrębną kwestię poruszaną $\mathrm{w}$ tej pracy stanowi problem osadnictwa okalającego analizowany obiekt. Truizmem jest stwierdzenie, że w większości przypadków wczesnośredniowieczny kościół znajduje się w centrum osady, na szczycie niewielkiego, choć wyraźnie zarysowanego w krajobrazie wzniesienia. W dotychczasowych opracowaniach zagadnienia osadnictwa w kontekście architektury nie były jednak dotąd podejmowane lub też pojawiały się niejako na marginesie. Przyjęta przeze mnie, celem analizy osadnictwa, jednostka czterech (w szczególnych przypadkach sześciu) arkuszy Archeologicznego Zdjęcia Polski dawała nadzieję na uchwycenie osad zlokalizowanych w odległości do $5 \mathrm{~km}$ od świątyni, w obszarze, który w świetle aktualnych badań Izabeli Skierskiej dotyczących ziem polskich, czy też Jana Klápštěgo dla ziem czeskich winien się charakteryzować największą gęstością zaludnienia. Materiał źródłowy wykorzystany na tak określonym obszarze pochodził przede wszystkim z badań powierzchniowych Archeologicznego Zdjęcia Polski oraz z badań wykopaliskowych, które w ogólnej liczbie stanowisk stanowią zasadniczo tylko niewielki procent. Wyniki badań poszczególnych obiektów/rejonów mają ogromny stopień zróżnicowania, przede wszystkim jakościowego. Studia nad zasiedleniem okolic Giecza potwierdziły wcześniejsze ustalenia Zofii Kurnatowskiej. Mam tu na myśli przede wszystkim okres plemienny, kiedy to rejon grodu gieckiego stanowił silne centrum osadnicze. Na północ od niego osadnictwo koncentrowało się w okolicach najwyższego wzniesienia w okolicy Górzna oraz na obu brzegach Moskawy. W późniejszym okresie, w którym powstał najstarszy z analizowanych przeze mnie obiektów, osadnictwo na analizowanym obszarze stało się rozproszone bardziej równomiernie, z wyraźnymi już początkami wsi zlokalizowanych w odległości 1-2 km wokół grodu, by wymienić choćby Borzejewo, Biskupice, Poświętne czy Dzierżnicę. Niestety, w pozostałych przypadkach mapy nie przedstawiają już tak wyraźnych jednostek osadniczych. Uwaga ta dotyczy nade wszystko terenów zlokalizowanych na obszarze byłego województwa konińskiego (Stare Miasto, Kościelec Kolski, Kazimierz Biskupi). W rejonie tym, w odróżnieniu od byłego woj. poznańskiego, wydzielano 
tylko dwa stadia osadnicze, tj. ślad osadniczy i osadę, z pominięciem tzw. punktu osadniczego. Wobec powyższego częste były przypadki określenia stanowiska jako osady, podczas gdy faktycznie odkryto zaledwie 2-3 fragmenty ceramiki naczyniowej.

Nieco lepiej przedstawia się siatka osadnicza rejonu Krobi, choć jest to raczej konsekwencja zlokalizowania na tym obszarze grodzisk w Pudliszkach, Karcu czy Nieparcie. Na pozostałej części tego obszaru trudno jest wskazać jakieś wyraźne skupiska. Szczególnie niejasna wydaje się sytuacja wsi Stara Krobia. Wieś ta, w świetle hipotezy Henryka Müncha, czy też późniejszych ustaleń Tadeusza Lalika, miała być pierwszym stadium rozwojowym miasta Krobia. Niestety, dane pochodzące z badań AZP nie potwierdzają tych ustaleń.

Chciałbym się odnieść jeszcze do Lubinia i jego okolic. Z uwagi na to, iż ogólny obraz osadnictwa tego rejonu został już wcześniej opracowany przez Zofię Kurnatowską, skupię się na kwestiach bardziej szczegółowych. Teren Lubinia i jego otoczenia jest chyba jedynym w Wielkopolsce, gdzie możliwa jest konfrontacja ustaleń historyka $\mathrm{z}$ danymi archeologicznymi pozyskanymi $\mathrm{w}$ większości $\mathrm{z}$ badań powierzchniowych w ramach akcji AZP. Analiza źródeł pisanych dotyczących posiadłości klasztoru lubińskiego, przeprowadzona przez Zbigniewa Perzanowskiego wykazała, że większość wsi, których właścicielami byli benedyktyni lubińscy, usytuowana była przede wszystkim w najbliższym sąsiedztwie opactwa. Poza nielicznymi wyjątkami można dostrzec przewagę osad powstałych w momencie erygowania opactwa oraz niewiele później, a większość tych osad przetrwała do dziś, jak się wydaje w pierwotnych miejscach. Być może pewne przetasowania wystąpiły w pobliżu cieków wodnych, założyć należy bowiem, że pierwotnie osadnictwo koncentrowało się w pobliżu doliny rzecznej. Przeprowadzona konfrontacja źródeł pisanych $\mathrm{z}$ wynikami badań powierzchniowych AZP dowiodła ogromnych dysproporcji w rozpoznaniu poszczególnych terenów w skali mikro. Owe braki stają się szczególnie dotkliwe, jeśli chcemy dokonać analizy w skali mikro dziejów zasiedlenia poszczególnych miejscowości. Obserwowana w źródłach pisanych ciągłość ich miejsca i nazwy nie wynika już z danych archeologicznych. Przedstawione w mojej dysertacji przykłady Stężycy i Szczodrochowa dość jednoznacznie wskazują pewne problemy z pozyskiwaniem czy też katalogowaniem materiałów późnośredniowiecznych. Wydaje się zatem, iż chcąc wykorzystać informacje o stanowiskach archeologicznych uzyskane na podstawie badań AZP należy zachować daleko posuniętą ostrożność, gdyż są one często bardzo słabo potwierdzone badaniami wykopaliskowymi, zarówno pod względem ilościowym, jak i jakościowym. Przedstawione zatem w pracy tzw. mapy osadnicze mogą mieć jedynie charakter orientacyjny, który ukazuje pewną ogólną dynamikę zmian oraz przybliżone rejony koncentracji osadnictwa. Próba sformułowania bardziej szczegółowych hipotez na podstawie tych źródeł obciążona jest zbyt dużym ryzykiem błędu.

Konkludując, należy stwierdzić, że niewątpliwe nadszedł już czas, aby ponownie podjąć badania nad jednonawowymi kościółkami w Polsce, badania, które objęłyby poza 
poruszanymi w tej pracy również kwestie kościoła prywatnego, działalności fundacyjnej dynastii panującej i możnych, co już wielokrotnie postulowano w literaturze, lecz na postulatach poprzestano.

\section{SINGLE-NAVE ROMANESQUE CHURCHES FROM THE WIELKOPOLSKA REGION (GREATER POLAND)}

\section{Su m m a r y}

'Rural' ecclesiae laicorum have remained mute witnesses of our history; they have been deserted, forgotten and frequently falling into ruin. Single-nave Romanesque churches from the territories of Poland have not been much interest for the scholars of the Middle Ages. A full monograph on such churches from Greater Poland has not been written yet. This remains in a striking opposition to analogues buildings from Western Pomerania, Silesia or the New March. The only incomplete and to a large extent outdated work on this subject is Stanisław Wiliński's paper Granite village churches of $12^{\text {th }}$ century in Greater Poland or an exiguous paper by Alicja Karłowska-Kamzowa addressing the question of their foundation.

The main aim of my book is the presentation of single-nave churches from Greater Poland erected in the period between the second half of the eleventh century and the end of the thirteenth century, in their historical and settlement context. Only churches that have been subject to archeological excavations have been included. Therefore, two factors determined whether a church has been chosen and included in this study: firstly, some archeological excavations must have been carried out within it, and secondly, the church must have played a basic role as a Christianization centre for 'rural' areas.

\section{Artur Różański}

Instytut Prahistorii, Uniwersytet im. Adama Mickiewicza ul. Św. Marcin 78, 61-809 Poznań, Poland 